\title{
Cytotoxicity and DNA damage in the neutrophils of patients with sickle cell anaemia treated with hydroxyurea
}

\author{
Alano Martins Pedrosa,", Maritza Cavalcante Barbosa ${ }^{1}$, Thayna Nogueira dos Santos ${ }^{1}$, \\ Luzia Kalyne Almeida Moreira Leal ${ }^{1}$, Amanda de Araújo Lopes ${ }^{1}$, Darcielle Bruna Dias Elias ${ }^{1}$, \\ Greyce Luri Sasahara1, Bruno Coêlho Cavalcanti², Romélia Pinheiro Gonçalves ${ }^{1}$
}

\begin{abstract}
'Pharmacy Department, Faculty of Pharmacy, Odontology and Nursing, Federal University of Ceará, Fortaleza, CE, Brazil, ${ }^{2}$ Physiology and Pharmacology Department, Faculty of Medicine, Federal University of Ceará, Fortaleza, CE, Brazil
\end{abstract}

\begin{abstract}
Hydroxyurea (HU) is the most important advance in the treatment of sickle cell anaemia (SCA) for preventing complications and improving quality of life for patients. However, some aspects of treatment with $\mathrm{HU}$ remain unclear, including their effect on and potential toxicity to other blood cells such as neutrophils. This study used the measurement of Lactate Dehydrogenase (LDH) and Methyl ThiazolTetrazolium (MTT) and the comet assay to investigate the cytotoxicity and damage index (DI) of the DNA in the neutrophils of patients with SCA using HU.In the LDH and MTT assays, a cytoprotective effect was observed in the group of patients treated, as well as an absence of toxicity. When compared to patients without the treatment, the SS group ( $\mathrm{n}=20,13$ women and 07 men, aged 18-69 years), and the group of healthy individuals (AA) used as a control group ( $\mathrm{n}=52,28$ women and 24 men, aged 19-60 years), The SSHU group ( $\mathrm{n}=21,11$ women and $10 \mathrm{men}$, aged 19-63 years) showed a significant reduction $(\mathrm{p}<0.001)$ in LDH activity and an increase in the percentage of viable cells by the MTT $(\mathrm{p}<0.001)$. However, the SSHU group presented significantly higher DI values (49.57 $\pm 6.0 \mathrm{U} / \mathrm{A})$ when compared to the AA group $(7.43 \pm 0,94 \mathrm{U} / \mathrm{A})$ and the SS group $(22.73 \pm 5.58 \mathrm{U} / \mathrm{A})(\mathrm{p}<0.0001)$, especially when treated for longer periods ( $>20$ months), demonstrating that despite the cytoprotective effects in terms of cell viability, the use of HU can induce DNA damage in neutrophils.
\end{abstract}

Uniterms: Hydroxyurea/cytotoxicity. Sickle cell anaemia/treatment. Neutrophils/DNA damage. Deoxyribonucleic acid/damage.

\begin{abstract}
A hidroxiuréia (HU) constitui o avanço mais importante no tratamento da anemia falciforme (AF) por prevenir complicações e aumentar a qualidade de vida dos pacientes. Entretanto, alguns aspectos do tratamento com HU permanecem obscuros, incluindo a sua ação e potencial toxicidade em outras células sanguíneas, tais como neutrófilos. Este estudo utilizou a mensuração da lactato desidrogenase (LDH) e do metil tiazoltetrazólio (MTT) e o ensaio do cometa para investigar a citotoxicidade e índice de dano (ID) ao DNA em neutrófilos de pacientes com AF em uso do medicamento. Nos ensaios de LDH e MTT, observou-se além de ausência de toxicidade, uma ação citoprotetora no grupo de pacientes tratados, Grupo SSHU ( $\mathrm{n}=21,11$ mulheres e 10 homens, com idades entre 19-63 anos), quando comparados aos pacientes sem tratamento, Grupo SS ( $\mathrm{n}=20,13$ mulheres e 07 homens, 18-69 anos), e grupo de indivíduos saudáveis (AA) usado como controle (n=52, 28 mulheres e 24 homens, 19-60 anos), com redução significativa $(\mathrm{p}<0,001)$ na atividade de LDH e aumento no percentual de células viáveis pelo MTT $(\mathrm{p}<0,001)$. Entretanto, o grupo SSHU apresentou valores de ID significativamente elevados $(49,57 \pm 6,0$ $\mathrm{U} / \mathrm{A})$, quando comparados ao grupo AA $(7,43 \pm 0,94 \mathrm{U} / \mathrm{A})$ e grupo SS $(22,73 \pm 5,58 \mathrm{U} / \mathrm{A})(\mathrm{p}<0,0001)$, especialmente quando tratados por períodos mais longos ( $>20$ meses), demonstrando que apesar dos efeitos citoprotetores quanto à viabilidade celular, o uso da HU pode induzir lesão ao DNA de neutrófilos.
\end{abstract}

Unitermos: Hidroxiuréia/citotoxicidade. Anemia falciforme/tratamento. Neutrófilos/lesão ao DNA. Ácido desoxirribonucleico/lesão.

\footnotetext{
*Correspondence: A. M. Pedrosa. Laboratório de Hematologia, Faculdade de Farmácia, Universidade Federal do Ceará. Rua Capitão Francisco Pedro, 1210 - Rodolfo Teófilo, 60370-430 - Fortaleza - CE, Brasil. E-mail: alano_martins@yahoo.com.br
} 


\section{INTRODUCTION}

Sickle cell anaemia (SCA) is a hereditary disease caused by the substitution of glutamic acid with valine in the sixth codon of the $\beta$-globin leading to the formation of haemoglobin $\mathrm{S}(\mathrm{HbS})$. The sickle red blood cell is rigid and inflexible, favoring the occurrence of vaso-occlusive and haemolytic events and starting a chain reaction that culminates with the generation of reactive oxygen species (ROS), reduced bioavailability of nitric oxide (NO) and the chronic inflammatory process, with direct involvement of neutrophils in the early stages and propagation of these mechanisms (Okpala, 2004; Conran et al., 2007; Rees, Gibson, 2011; Chirico, Pialoux, 2012).

The leukocytes play an important role in the pathophysiology of SCA. The vaso-occlusive process and endothelial injury result in a chronic inflammatory response characterized by high levels of proinflammatory cytokines, which are capable of making the activated endothelium. The endothelial activation results in increased expression of adhesion molecules on neutrophils, such as E-selectin, P-selectin and ICAM-1 (Intercellular Adhesion Molecule-1), inducing the chemotaxis of neutrophils and its interaction with adhesion molecules on sickle red blood cells, other leukocytes and platelets, leading to pancellular activation resulting in the release of most proinflammatory cytokines. Thus, there is a vicious circle between production of inflammatory mediators and cellular adhesion to the endothelium, leading to a state of chronic inflammation, fundamental to the process of vaso-occlusion (Okpala, 2006; Canalli et al., 2008; Conran, Franco-Penteado, Costa, 2009; Segel, Halterman, Lichtman, 2011).

The high count of neutrophils, often seen in patients with SCA, even in the absence of infection, has been associated with the occurrence of painful crises, acute chest syndrome (ACS), cerebrovascular accident (CVA) and early death; however, the mechanisms responsible for this are not completely understood (Platt et al., 1994; Castro et al., 1994; Ohene-Frempong et al., 1998). Some factors that may cause the interruption of apoptosis, such as proinflammatory cytokines, cell adhesion, hypoxia, and transmigration of bacterial lipopolysaccharide (LPS) may be related to the increased number of neutrophils and the survival time of these cells, suggesting an important relevance to the pathogenesis of SCA, since changes in the processes of apoptosis may affect cellular function and increase the damage potential (Ohene-Frempong et al., 1998; Moulding et al., 1998; Cross et al., 2005; Cross et al., 2006; Conran et al., 2007).

Hydroxyurea (HU) is the only drug approved by the U.S. Food and Drug Administration (1999) and European
Medicines Agency (2008) for the treatment of SCA. HU inhibits the enzyme ribonucleotide reductase (RNR), causes cell-cycle arrest, and allows globin genes to be more actively expressed. By killing cycling cells, HU changes the kinetics of erythroid proliferation, forcing more $\mathrm{F}$ cells to be produced from primitive progenitors and directly stimulating $\mathrm{HbF}$ production (Franco et al., 2006).Furthermore, HU therapy increases haemoglobin concentration, reduces the expression of adhesion molecules on erythrocytes, platelets and neutrophils, decreases the production of granulocytes and contributes to the improvement of clinical events, reducing the number of hospital admissions, the frequency of painful episodes, the need for transfusion and the occurrence of CVA and ACS (Platt et al., 1984; Steinberg et al., 2003; Zago, Pinto, 2007; Cartron, Elion, 2008; Orah, Platt, 2008; Conran, Franco-Penteado, Costa, 2009; Lou et al., 2009).

Despite these benefits the HU therapy may have clastogenic, mutagenic and teratogenic effects (Murphy, Chaube, 1964; Oppenheim, Fishbein, 1965; Aliverti, Bonanomi, Giavini, 1980; Ware, Aygun, 2009). In the literature, the HU ability to cause cancer is controversial and the long-term efficacy and safety of HU in treating patients with SCA remains inconclusive (Steinberg et al., 2010). Some studies have shown that HU is genotoxic while other studies suggest that $\mathrm{HU}$ has low mutagenicity in vivo (Hanft et al., 2000; Friedrisch et al., 2008). Furthermore, some reports relate that HU acts as a competitive inhibitor of catalase-mediated hydrogen peroxide decomposition and this effect could be related to in vivo toxicity (Juul et al., 2010).

The long term safety of using HU remains an important issue, especially regarding genotoxicity and cell damage, and impact on the function of different organs (spleen kidneys, brain, lings) (Cançado et al., 2009).

Thus, some aspects regarding the treatment with HU and the safety of its long term use are still not fully elucidated, especially its effect on other blood cells other than erythrocytes. Therefore, it is necessary to evaluate the effect of HU regarding the genotoxicity and cytotoxicity in neutrophils isolated from patients with sickle cell anaemia at baseline, seeking evidence about the effect of HU on these cells and its influence on the modulation of the chronic inflammatory process in these patients.

\section{MATERIAL AND METHODS}

\section{Criteria for inclusion}

\section{Subjects and samples}

This is a cross-sectional study of 41 adult patients 
(24 women and 17 men, aged 18-69 years) with clinical and laboratory diagnosis (confirmed by haemoglobin electrophoresis and molecular biology) of sickle cell anaemia (homozygotic SS form), representing 50\% of the patients attending the outpatient unit of the haematology service of a reference hospital in Fortaleza, CE, Brazil (Table I presents the characteristics and clinical details of all individuals participating in the study). The study included SCA patients in a stable condition, according to the criteria of Ballas: absence of painful episodes and/or intercurrent illnesses, such as infections and inflammations in the four weeks preceding the study; no hospital admissions in the 2-3 days preceding the study and no blood transfusions in the four months preceding the study (Ballas, 2012).

In Brazil, the Ministry of Health degree $n^{\circ} 872$ of 6 th November 2002 approved the use of HU for patients with sickle cell disease. The drug is recommended for patients with a laboratory diagnosis of sickle cell disease (HbSS, $\mathrm{S} / \beta$ Thalassemia, $\mathrm{HbSC}, \mathrm{Hb} \mathrm{SD})$, including children with three or more episodes of vaso-occlusive crises requiring hospital medical care; a recurring acute chest crises; one or more strokes; recurrent priapism and severe and persistent anaemia in the past 12 months, Hb concentration consistently less than $7 \mathrm{~g} / \mathrm{dL}$, concentration of fetal $\mathrm{Hb}<8 \%$ after 2 years of age, WBC count $20 \times 10^{9} / \mathrm{L}$ in the absence of infection. Patients with hypersensitivity to HU will be excluded from this protocol, as well as patients with presence of at least one of the following items related to bone marrow dysfunction: neutrophils $<2.5 \times 10^{9} / \mathrm{L}$, platelets $<95 \times 10^{9} / \mathrm{L}, \mathrm{Hb}$ concentration $<4.5 \mathrm{~g} / \mathrm{dL}$ or reticulocyte count $<95 \times 10^{9} / \mathrm{L}$, pregnant women and HIV-infected patients (Brazil, 2002; Cançado et al., 2009).
The selected patients were divided into two groups according to the use of HU: SS (without HU treatment) $(\mathrm{n}=20,13$ women and 07 men, aged 18-69 years) and SSHU (receiving oral HU dose between 15 and $25 \mathrm{mg} / \mathrm{kg} /$ day $)(\mathrm{n}=21,11 \mathrm{women}$ and $10 \mathrm{men}$, aged 19-63 years). A control group (AA) was made up of 52 healthy blood donors ( 28 women and 24 men, aged 19-60 years) from a blood center in Fortaleza, CE, Brazil. Exclusion criteria for all groups were: presence of infectious diseases (HIV-1 and 2, HBsAg, HCV and HTLV-1 \& 2), pregnancy, presence of renal failure or liver disease, smoking, alcohol consumption, use of chelated iron, anti-inflammatory drugs, antioxidant vitamins, or any immunosuppressant. The survey was approved by the Ethics Committee of the Federal University of Ceará (COMEP/Protocol number 101/12), and all subjects signed an informed consent form. Samples $(10 \mathrm{~mL})$ of peripheral blood were collected with EDTA for molecular biology. Samples $(10 \mathrm{~mL})$ of heparinized peripheral blood were collected for isolation of polymorphonuclear leukocytes, predominantly neutrophils.

\section{Molecular biological analysis}

Molecular diagnosis of patients was based on a Polymerase Chain Reaction for mediated Restriction Fragment Length Polymorphism (PCR-RFLP), by digestion with DdeI restriction enzyme, according to the methods of Saiki et al. (1985).

\section{Isolation of polymorphonuclear leukocytes}

The isolation of polymorphonuclear leukocytes was carried from whole blood by differential gradient

TABLE I -Characteristics and clinical details of the control group and patients with sickle cell anemia participating in the study

\begin{tabular}{|c|c|c|c|}
\hline & $A A(n=52)$ & $S S(n=20)$ & $\operatorname{SSHU}(n=21)$ \\
\hline Male/Female & $24 / 28$ & $07 / 13$ & $10 / 11$ \\
\hline Age (years) & $34.6(19 ; 60)$ & $30(18 ; 69)$ & $32.17(19 ; 63)$ \\
\hline Red blood cell count $\left(\mathrm{x} 10^{12} / \mathrm{L}\right)$ & $4.6(4.2 ; 5.7)$ & $2.66(1.77 ; 4.0)$ & $2.61(1.73 ; 3.82)$ \\
\hline Haemoglobin $(\mathrm{g} / \mathrm{dL})$ & $13.5(12.2 ; 15.2)$ & $8.4(5.8 ; 11.5)$ & $9.5(7.4 ; 11.7)$ \\
\hline Haematocrit(\%) & $41(37 ; 49)$ & $24.33(16.9 ; 32.9)$ & $27.05(21.8 ; 33.4)$ \\
\hline $\mathrm{MCV}(\mathrm{fL})$ & $87(79 ; 92.1)$ & $91.1(74.4 ; 107.6)$ & $103.4(79.7 ; 130.4)$ \\
\hline $\mathrm{MCH}(\mathrm{pg})$ & $28.9(25.9 ; 31.6)$ & $31.5(28.7 ; 37.7)$ & $36.2(29.5 ; 45.5)$ \\
\hline White blood cell $\left(\mathrm{x} 10^{9} / \mathrm{L}\right)$ & $5.7(4.1 ; 8.4)$ & $13.7(5.5 ; 22.1)$ & $9.4(4.0 ; 19.7)$ \\
\hline Neutrophil(\%) & $47(39 ; 51)$ & $59(39 ; 85)$ & $47.2(31 ; 72)$ \\
\hline Reticulocytes $\left(\times 10^{3} / \mu \mathrm{L}\right)$ & UD & $272.5(110.9 ; 597.8)$ & $235.4(110.5 ; 433.3)$ \\
\hline Platelets $\left(\right.$ x $\left.10^{6} / \mu \mathrm{L}\right)$ & $220(148 ; 312)$ & $371(154 ; 798)$ & $388.2(385 ; 880.4)$ \\
\hline $\mathrm{HbF}(\%)$ & UD & $5.66(1.0 ; 13.8)$ & $15.77(6.0 ; 38.7)$ \\
\hline
\end{tabular}

AA: Control group (healthy individuals); SS: patients with sickle cell anaemia not treated with HU; SSHU: patients with sickle cell anaemia treated with HU; MCV: Mean Corpuscular Volume; MCH: Mean Corpuscular Haemoglobin; UD: Undetermined. The figures presented (except $\mathrm{M} / \mathrm{F}$ ) represent the average (minimum and maximum). 
using a gelatin solution, following the methodology proposed by Henson (1971) and modified by Lucisano and Mantovani (1984) in which the cells were suspended in buffered Hank's balanced solution, containing calcium and magnesium. The preparations contained predominantly neutrophils $(85.0 \pm 2.8 \%)$.

\section{Cell viability assay}

Cell viability was determined by a Trypan Blue dye exclusion assay, in which the neutrophil suspension $\left(2.5 \times 10^{6} / \mathrm{mL}\right)$ was mixed with an equal volume of Trypan Blue dye, $0.1 \%$, and transferred to a Neubauer chamber. The Trypan Blue dye incorporated only non-viable cells due to membrane lesions (Lucisano, Mantovani, 1984). The proportion of viable cells was estimated by counting 200 cells in an optical microscope.

\section{Cytotoxicity assays}

The cytotoxicity was analyzed by lactatedehydrogenase (LDH) release, which assesses cell death by necrosis, and by the MethylThiazolTetrazolium (MTT) assay, measuring cellular metabolic activity through the pathway succinate-tetrazolium redutase, enzyme active only in cells with intact respiratory metabolism, which reduces the tetrazolium salt (yellow coloration) to a salt purple colour (formazan) (Renzi, Valtolina, Forster, 1993).

After isolation, a suspension of cells $\left(2.5 \times 10^{6} / \mathrm{mL}\right)$ was incubated with buffered Hank's balanced solution (test group) or $0.2 \%$ Triton X-100 (known to cause cell lysis and used as a positive control), for $30 \mathrm{~min}$ at $37^{\circ} \mathrm{C}$. The activity of LDH was determined in the supernatant according to the manufacturer's instructions (LDH liquiform of Labtest Diagnosis, MG, Brazil) in which the consumption of NADH was monitored by conversion of pyruvate to lactate at $340 \mathrm{~nm}$. A solution of MTT at a concentration of $10 \mathrm{mg} / \mathrm{mL}$ was added to a cell suspension of neutrophils $\left(5.0 \times 10^{6} / \mathrm{mL}\right)$ for the colorimetric determination of the formazan crystals at $540 \mathrm{~nm}$, according to the protocol described by Mosmann (1983).

\section{Comet assay}

The standard alkaline protocol for comet assay was used, as reported by Singh et al. (1988). The assay was performed in accordance with general guidelines for in vivo use of the comet assay (Tice et al., 2000; Hartmann et al., 2003). Briefly, the neutrophil suspension $\left(2.5 \times 10^{6}\right.$ cells $/ \mathrm{mL}$ ) was mixed with low-melting-point agarose and spread onto glass slides pre-coated with agarose, and cover slips were gently placed over their content. Once the samples solidified, the cover slips were removed and the slides were soaked in freshly made, chilled lysis solution (2.5M NaCl, $100 \mathrm{mM}$ EDTA, $10 \mathrm{mM}$ Tris, $\mathrm{pH}$ 10.2 , to which $1 \%$ Triton X-100 and 10\% DMSO had been added) for 1-2 days under refrigeration. Excess liquid was blotted away from each slide's back and edges; the slides were then transferred to an electrophoresis tank, and an alkaline solution $(300 \mathrm{mM} \mathrm{NaOH}, 1 \mathrm{mM}$ EDTA, $\mathrm{pH}>13$ ) was added. The slides were exposed to the alkaline solution for 20 min to allow for DNA unwinding and for the expression of alkali-labile sites as single strand breaks. DNA was then electrophoresed for $20 \min (25 \mathrm{~V} ; 300 \mathrm{~mA}$; $0.9 \mathrm{~V} / \mathrm{cm})$. Slides were removed from the electrophoresis tank, cleaned, washed three times ( 5 min each time) with neutralization buffer $(0.4 \mathrm{M}$ Tris, $\mathrm{pH} 7.5)$, washed three times with distilled water, and allowed to air dry. All steps of the assay were conducted under dim light.

Slides were then fixed and silver-stained according to the methods of Nadin, Vargas-Roig and Ciocca (2001). For evaluation of DNA damage, 100 cells per subject were analyzed at 200x magnification under a light microscope. Cells were assessed visually and received scores from 0 (no migration) to 4 (maximum migration) according to tail intensity (size and shape). Therefore, the total scores (damage index or DI) for 100 cells ranged from 0 (all cells with no migration) to 400 (all cells with maximum migration). Slides from patients and controls were processed, coded, mixed, and evaluated together.

\section{Statistical analyses}

The Statistical Package for the Social Sciences (SPSS) 10.0 for Windows was used for all data analyses, and graphs were made with the GraphPad Prism 4.0 for Windows. The level of significance was 0.05 for all tests, and the data is presented as mean \pm S.E. of the mean (SEM). The Kolmogorov-Smirnov test was used to check for normal distribution of the data. The Analysis of variance (ANOVA) followed by the Tukey post-test was used to determine statistical differences between groups AA, SS and SSHU. The parametric T-test was used to test the influence of the mean dose of HU and HU Length of treatment on LDH release, MTT reduction and DI values. The mean dose of HU and the treatment length were separated into two categories according to their medians.

\section{RESULTS}

\section{Influence of treatment with $\mathrm{HU}$ on cell viability evaluated by exclusion assay with Trypan Blue dye in neutrophils from patients with sickle cell anaemia}

Table II shows that the number of viable cells of the SS group $(93.7 \pm 0.34 \%)$ was significantly lower than 
in the AA group $(95.8 \pm 0.29 \%)(\mathrm{p}<0.05)$. The number of viable cells in the SSHU group (95.0 $\pm 0.42 \%)$ was similar to the SS and control groups, i.e., there was no significant difference.

TABLE II - Influence of treatment with HU on cell viability evaluated by exclusion assay with Trypan Blue dye in neutrophils from patients with sickle cell anaemia

\begin{tabular}{lccc}
\hline & \multicolumn{2}{c}{ Numberofcells $(\%)$} & \\
\cline { 2 - 4 } & Viable & Non-viable & $p$ \\
\hline AA $(\mathrm{n}=52)$ & $95.8 \pm 0.29$ & $4.2 \pm 0.33$ & $\mathrm{p}>0.05$ \\
$\mathrm{SS}(\mathrm{n}=20)$ & $93.7 \pm 0.34^{\mathrm{a}}$ & $6.2 \pm 0.35$ & $\mathrm{p}<0.05$ \\
$\mathrm{SSHU}(\mathrm{n}=21)$ & $95.0 \pm 0.42$ & $5.0 \pm 0.42$ & $\mathrm{p}>0.05$ \\
\hline
\end{tabular}

AA: Control group (healthy individuals), SS: patients with sickle cell anaemia not treated with HU; SSHU: patients with sickle cell anaemia treated with HU. Results were expressed as mean \pm SEM. ANOVA followed by Tukeypost test. ${ }^{a} \mathrm{p}<0.05$ versus AA group.

\section{Influence of treatment with $\mathrm{HU}$ on $\mathrm{LDH}$ release and MTT reduction in neutrophils from patients with sickle cell anaemia}

Table III shows that the SS group $(10.25 \pm 1.21 \mathrm{U} / \mathrm{L})$ showed a greater LDH release compared to the AA group
$(6.71 \pm 0.68 \mathrm{U} / \mathrm{L})$ and the SSHU group $(5.59 \pm 0.37 \mathrm{U} / \mathrm{L})$ $(\mathrm{p}=0.0003)$. The LDH release did not differ between the SSHU and the AA groups ( $p>0.05)$.In the experimental model MTT reduction, the SS group (35.14 $\pm 2.32 \%)$ showed a lower number of viable cells when compared to the AA group (56.8 $\pm 3.2 \%)$ and the SSHU group (50.59 \pm $3.64 \%)(p<0.0001)$. There was no significant difference between the number of viable cells in the SSHU and the AA groups ( $p>0.05)$. The mean dose of HU and the Length of HU treatment did not affect the LDH release and MTT reduction (Table IV).

\section{Influence of treatment with HU in the DI values in neutrophils from patients with sickle cell anaemia}

Figure 1 shows an association between DI values and treatment with HU. DI values for the SSHU group were greater $(49.57 \pm 6.0 \mathrm{U} / \mathrm{A})$ when compared to the AA group $(7.43 \pm 0.94 \mathrm{U} / \mathrm{A})$ and the $\mathrm{SS}$ group $(22.73 \pm 5.58$ $\mathrm{U} / \mathrm{A})(\mathrm{p}<0.0001)$. The SS group showed DI values higher than in the AA group, but the difference was not significant ( $p>0.05)$. The mean dose of HU and the Length of HU treatment did not affect the DI values (Table IV).

\section{DISCUSSION}

The clinical and laboratory efficacy of HU in the

TABLE III - Influence of treatment with HU in the parameters of cytotoxicity in neutrophils from patients with sickle cell anaemia

\begin{tabular}{lcccc}
\hline Parameters & AA $(\mathrm{n}=52)$ & SS $(\mathrm{n}=20)$ & SSHU $(\mathrm{n}=21)$ & $p$ \\
\hline LDH release (U/L) & $6.71 \pm 0.68$ & $10.25 \pm 1.21^{\mathrm{a}}$ & $5.59 \pm 0.37^{\mathrm{b}}$ & 0.0003 \\
MTT reduction (\% de viable cells) & $56.80 \pm 3.20$ & $35.14 \pm 2.32^{\mathrm{a}}$ & $50.59 \pm 3.64^{\mathrm{b}}$ & $<0.0001$ \\
\hline AA: Conct
\end{tabular}

AA: Control group (healthy individuals), SS: patients with sickle cell anaemia not treated with HU; SSHU: patients with sickle cell anaemia treated with HU. Results were expressed asmean \pm SEM. ANOVA followed by Tukeypost test. ${ }^{a} p<0.05$ versus AA group, ${ }^{\mathrm{b}} \mathrm{p}<0.05$ versus SS group

TABLE IV - LDH release, MTT reduction and DNA damage according to length of HU treatment and mean HU dose (SSHU group) $(\mathrm{n}=21)$

\begin{tabular}{lcccccc}
\hline & $\begin{array}{c}\text { LDH release } \\
(\mathrm{U} / \mathrm{L})\end{array}$ & $p$ & $\begin{array}{c}\text { MTT reduction } \\
(\% \text { de viable cells })\end{array}$ & $p$ & $\begin{array}{c}\text { DI values } \\
(\mathrm{U} / \mathrm{A})\end{array}$ & $p$ \\
\hline $\begin{array}{c}\text { Mean dose of } \mathrm{HU}(\mathrm{n}) \\
<20.0 \mathrm{mg} / \mathrm{kg} \mathrm{HU}(15)\end{array}$ & $6.18 \pm 0.68$ & 0.289 & $51.60 \pm 8.43$ & 0.825 & $51.70 \pm 5.70$ & 0.098 \\
$\quad 20.0 \mathrm{mg} / \mathrm{kg} \mathrm{HU}(6)$ & $5.32 \pm 0.44$ & & $49.90 \pm 3.18$ & & $28.67 \pm 7.39$ & \\
Length of HU treatment $(n)$ & & & & & & \\
$\quad \leq 2$ months (8) & $5.88 \pm 0.64$ & 0.925 & $44.81 \pm 3.44$ & 0.220 & $25.92 \pm 7.10$ & $0.002^{*}$ \\
$\quad$ 20months (13) & $5.81 \pm 0.44$ & & $51.12 \pm 3.56$ & & $59.0 \pm 6.39$ & \\
\hline
\end{tabular}

Results were expressed as mean \pm SEM. Student t-Test. $* p<0.05$. 


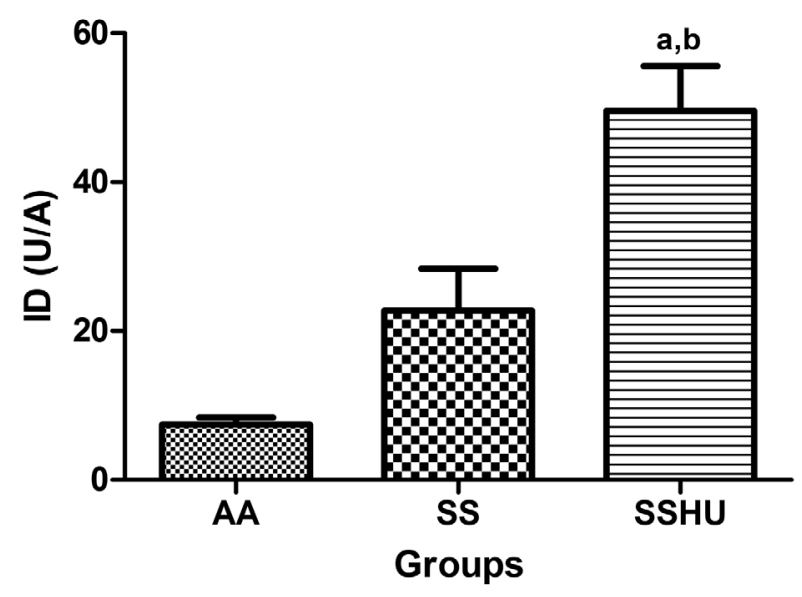

FIGURE 1 - Influence of treatment with HU on the DI values in neutrophils from patients with sickle cell anaemia. AA: Control group (healthy individuals) $(\mathrm{n}=52)$; SS: patients with sickle cell anaemia not treated with $\mathrm{HU}(\mathrm{n}=20)$; SSHU: patients with sickle cell anaemia treated with HU $(n=21)$. Results were expressed as mean \pm SEM. ANOVA followed by turkey posttest. ${ }^{\mathrm{a}} \mathrm{p} 0.05$ versus AA group. ${ }^{\text {b }} 0.05$ versus $\mathrm{SS}$ group

treatment of SCA has been convincingly demonstrated, with a decrease in morbidity and mortality with HU use, coupled with the modest short-term toxicity profile and ease of once daily oral administration, HU is an ideal treatment option (Ware, 2010). These consistent results leave little question as to the clinical benefits of $\mathrm{HU}$ therapy for adults with SCA. However, the long-term efficacy and safety of HU use for patients with SCA remains one of the most critical unanswered questions (Brawley et al., 2008), and not much is known about the effects of this medicament on neutrophils and on the functionality of these cells, since the majority of the studies found in the literature are related to red blood cells.

The results of this study showed that patients with SCA not treated with HU showed significantly lower cell viability, both the cellular viability assay by Trypan Blue dye as well as the MTT assay, and increased LDH release compared to the control group (AA). Similar results are found in studies with erythrocytes of SCA patients, revealing an increase in plasma levels of $\mathrm{LDH}$ of patients when compared to healthy individuals (Kato et al., 2006; Cançado et al., 2009), and this increase in enzymes is positively associated with an increased risk that patients will suffer from priapism, pulmonary hypertension, cutaneous ulcers in the lower limbs, resistance to NO or even early death (Kato et al., 2006; Steinberg, 2008; Rees, Gibson, 2011). There was no significant difference of these variables between the patients treated with HU and the control group (AA). These results suggest that neutrophils from patients with SCA not treated with HU do have damage of cellular integrity and respiratory metabolism, and that HU did not have any cytotoxic effect on patients' neutrophils when investigated using these testing models. However, a cytoprotective action was revealed when compared to the AA group and the SS patients. It is also possible that the oxidative stress and generalized inflammation of severe untreated SCA produces a mild cytotoxic effect, and HU therapy may help to improve this process.

To evaluate the DNA damage index by comet assay, it was observed that the SCA patients not treated with HU had DI values higher than the AA group, but with no significant difference. No correlation was observed between the DI values with the HbF parameters and the total white blood cell count in the groups studied. Some studies show conflicting results, suggesting that mutagenic or carcinogenic effects are induced by the disease itself rather than by HU therapy (Schultz, Ware, 2003; Segal et al., 2008). For example, in a retrospective survey by the International Association of Sickle Cell Nurses and Physician Assistants, 52 cases of cancer were identified in a cohort of more than 16,000 patients with SCA; almost all occurred in the pre-HU stage; only three patients had previous HU exposure; among children with SCA, 21 reported cancers included leukemia $(n=7)$, Wilms tumor $(\mathrm{n}=5)$, lymphoma $(\mathrm{n}=3)$, and six other solid tumors; only one patient with acute lymphoblastic leukemia had previous HU exposure (Schultz, Ware, 2003).

There are conflicting reports regarding the DNAdamaging potential of HU in exposed humans. Some studies have shown that HU is genotoxic (Flanagan et al., 2010; Juul et al., 2010; Santos et al., 2011) while other studies suggest that HU has low mutagenicity in vivo (Stricker et al., 1986; Dawkins et al., 1997; Montalembert et al., 1999; Hanft et al., 2000; Montalembert, Davies, 2001; Moschovi et al., 2001). In this study, patients with SCA treated with HU had significantly elevated DI values when compared with the patients with SCA who were not treated with HU. Furthermore, the DI values were significantly higher in patients treated for longer periods ( $>20$ months). Similar results were found in two previous studies that evaluated the DNA Damage Index in total peripheral white blood cell counts of SCA patients treated with HU (Friedrisch et al., 2008; Rocha et al., 2012). Taken together, these studies provide evidence for measurable genotoxicity from $\mathrm{HU}$ exposure in patients with SCA, but little evidence to support cumulative mutagenicity or carcinogenic potential.

\section{CONCLUSION}

Although HU presents numerous positive responses, more studies on the issue of safety are essential, including 
the optimal dosage, the duration of use and the age of the patient, among other factors. Currently SCA is characterized as a chronic inflammatory disease where neutrophils initiate leukocyte adhesion to blood vessel walls, contributing thus to the development of inflammatory and vaso-occlusive processes and to the severity of the disease. Despite evidence of the essential involvement of neutrophils in the clinical modulation and the pathophysiological aspects of the disease, the mechanism by which HU modulates this effect is not fully elucidated. This study demonstrates that treatment with HU does not exert a cytotoxic effect on the neutrophils of patients with SCA, and HU may even be able to promote a protective effect on these cells, however there is the risk of DNA damage associated with exposure for longer periods of time. The monitoring of patients with SCA is important, since the data on the cytotoxic and genotoxic risks of $\mathrm{HU}$ remain inconclusive. More research is needed to clarify the risks of HU therapy inpatients with SCA.

\section{CONFLICT OF INTEREST STATEMENT}

The authors declare that there are no conflicts of interest.

\section{REFERENCES}

ALIVERTI, V.; BONANOMI, L.; GIAVINI, E. Hydroxyurea as a reference standard in teratological screening. In: CHAMBERS, P.L.; KLINGER, W.(Eds.)Further studies in the assessment of toxic actions. Springer, 1980. p.239-247.

BALLAS, S.K. More definitions in sickle cell disease: steady state v base line data. Am. J. Hematol., v.87, n.3, p.338, 2012.

BRASIL. Ministério da Saúde. Portaria SAS/MS No 872, de 06 de novembro de 2002, publicada no Diário Oficial da União, de 8 de novembro de 2002, seção 1, página 169 Aprova o protocolo clínico e diretrizes terapêuticas /Doença Falciforme/ Hidroxiuréia. Secretário Renilson Rehem de Souza.

BRAWLEY, O.W.; CORNELIUS, L.J.; EDWARDS, L.R.; GAMBLE, V.N.; GREEN, B.L.; INTURRISI, C.; JAMES, A.H.; LARAQUE, D.; MENDEZ, M.; MONTOYA, C.J. National institutes of health consensus development conference statement: hydroxyurea treatment for sickle cell disease. Ann. Intern. Med., v.148, n.12, p.932-938, 2008.
CANÇADO, R.D.; LOBO, C.; ANGULO, I.L.; ARAÚJO, P.I.C; JESUS, J.A. Protocolo clínico e diretrizes terapêuticas para uso de hidroxiureia na doença falciforme. Rev. Bras. Hematol. Hemoter., v.31, n.5, p.361-366, 2009.

CANNALLI, A.A.; FRANCO-PENTEADO, C.F.; SAAD, S.T.O.; CONRAN, N.; COSTA, F.F. Increased adhesive properties of the neutrophils in sickle cell disease may be reversed by pharmacological nitric oxide donation. Haematologica, v.93, n.4, p.605-609, 2008.

CARTRON, J.P.; ELION, J. Erythroid adhesion molecules in sickle cell disease: effect of hydroxyurea. Transfus. Clin. Biol., v.15, n.1, p.39-50, 2008.

CASTRO, O.; BRAMBILLA, D.J.; THORINGTON, B.; REINDORF, C.A.; SCOTT, R.B.; GILLETTE, P.; VERA, J.C.; LEVY, P.S. The acute chest syndrome in sickle cell disease: incidence and risk factors. The cooperative study of sickle cell disease. Blood, v.84, n.2, p.643-649, 1994.

CHIRICO, E.N.; PIALOUX, V. Role of oxidative stress in the pathogenesis of sickle cell disease. Life, v.64, n.1,p.72-80, 2012.

CONRAN, N.; ALMEIDA, C.B.; LANARO, C.; FERREIRA, R.P.; TRAINA, F. SAAD, S.T.O.; COSTA, F.F. Inhibition of caspase-dependent spontaneous apoptosis via a cAMPprotein kinase A dependent pathway in neutrophils from sickle cell disease patients. Br. J. Haematol., v.139, n.1, p.148-158, 2007.

CONRAN, N.; FRANCO-PENTEADO, C.F.; COSTA, F.F. Newer aspects of the pathophysiology of sickle cell disease vaso-occlusion. Hemoglobin, v.33, n.1, p.1-16, 2009.

CROSS, A.; BAKSTAD, D.; ALLEN; J.C.; THOMAS, L.; MOOTS, R.J.; EDWARDS, S.W. Neutrophil gene expression in rheumatoid arthritis. Pathophysiology, v.12, n.3, p.191-202, 2005.

CROSS, A.; BARNES, T.; BUCKNALL, R.C.; EDWARDS, S.W.; MOOTS, R.J. Neutrophil apoptosis in rheumatoid arthritis is regulated by local oxygen tensions within joints. J. Leukoc. Biol., v.80, n.3, p.521-528, 2006.

DAWKINS, F.W.; KIM, K.S.; SQUIRES, R.S.; CHISHOLM, R.; KARK, J.A.; PERLIN, E.; CASTRO, O. Cancer incidence rate and mortality rate in sickle cell disease patients at Howard University Hospital: 1986-1995. Am. J. Hematol., v.55, n.4,p.188-192, 1997. 
FLANAGAN, J.M.; HOWARD, T.A.; MORTIER, N.; AVLASEVICH, S.L.; SMELTZER, M.P.; WU, S.; DERTINGER, S.D.; WARE, R.E. Assessment of genotoxicity associated with hydroxyurea therapy in children with sickle cell anemia. Mutat. Res., v.698, n.1-2, p.38-42, 2010.

FRANCO, R.S.; YASIN, Z.; PALASCAK, M.B.; CIRAOLO, P.; JOINER, C.H.; RUCKNAGEL, D.L. The effect of fetal hemoglobin on the survival characteristics of sickle cells. Blood, v.108, n.3, p.1073-1076, 2006.

FRIEDRISCH, J.R.; PRÁ, D.; MALUF, S.W.; BITTAR, C.M.; MERGENER, M.; POLLO, T.; KAYSER, M.; DA SILVA, M.A.L.; HENRIQUES, J.A.P.; DA ROCHA SILLA, L.M. DNA damage in blood leukocytes of individuals with sickle cell disease treated with hydroxyurea. Mutat. Res., v.649, n.1, p.213-220, 2008.

HANFT, V.N.; FRUCHTMAN, S.R.; PICKENS, C.V.; ROSSE, W.F.; HOWARD, T.A.; WARE, R.E. Acquired DNA mutations associated with in vivohydroxyurea exposure. Blood, v.95, n.11, p.3589-3593, 2000.

HARTMANN, A.; AGURELL, E.; BEEVERS, C.; BRENDLER-SCHWAAB, S.; BURLINSON, B.; CLAY, P.; COLLINS, A.; SMITH, A.; SPEIT, G.; THYBAUD, $\mathrm{V}$. Recommendations for conducting the in vivo alkaline comet assay. $4^{\text {th }}$ International Comet Assay Workshop. Mutagenesis, v.18, n.1, p.45-51, 2003.

HENSON, P.M. The immunology release of constituents from neutrophils leukocytes. J. Immunol., v.107, n.6, p.15351546, 1971.

JUUL, T.; MALOLEPSZY, A.; DYBKAER, K.; KIDMOSE, R.; RASMUSSEN, J.T.; ANDERSEN, G.R.; JOHNSEN, H.E.; JØRGENSEN, J.; ANDERSEN, S.U. The in vivo toxicity of hydroxyurea depends on its direct target catalase. J. Biol. Chem., v.285, n.28, p.21411-21415, 2010.

KATO, G.J.; MCGOWAN, V.; MACHADO, R.F.; LITTLE, J.A.; TAYLOR, J.; MORRIS, C.R.; NICHOLS, J.S.; WANG, X.; POLJAKOVIC, M.; MORRIS, S.M. Lactate dehydrogenase as a biomarker of hemolysis-associated nitric oxide resistance, priapism, leg ulceration, pulmonary hypertension, and death in patients with sickle cell disease. Blood, v.107, n.6, p. 2279-2285, 2006.
LOU, T.F.; SINGH, M.; MACKIE, A.; LI, W.; PACE, B.S. Hydroxyurea generates nitric oxide in human erythroid cells: mechanisms for gamma-globin gene activation. Exp. Biol. Med., v.234, n.11, p.1374-1382, 2009.

LUCISANO, Y.M.; MANTOVANI, B. Lysossomal enzyme release from polymorfonuclear leukocytes induced by immune complexes of IgM and IgG. J. Immunol., v.132, n.4, p.2015-2020, 1984.

MONTALEMBERT, M.; BEGUE, P.; BERNAUDIN, F.; THURET, I.; BACHIR, D.; MICHEAU, M. Preliminary report of a toxicity study of hydroxyurea in sickle cell disease. Arch. Dis. Child, v.81, n.5, p.437-439, 1999.

MONTALEMBERT, M.; DAVIES, S.C. Is hydroxyurea leukemogenic in children with sickle cell disease? Blood, v.98, n.9, p.2878-2879, 2001.

MOSCHOVI, M.; PSYCHOU, F.; MENEGAS, D.; TSANGARIS, G.T.; TZORTZATOU-STATHOPOULOU, F.; NICOLAIDOU, P. Hodgkin's disease in a child with sickle cell disease treated with hydroxyurea. Pediatr. Hematol. Oncol., v.18, n.6, p.371-376, 2001.

MOSMANN, T. Rapid colorimetric assay for cellular growth and survival: application to proliferation and cytotoxicity assays. J. Immunol. Methods, v.65, n.1-2, p.55-63, 1983.

MOULDING, D.A.; QUAYLE, J.A.; HART, A.; EDWARDS, S.W. Mcl-1 expression in human neutrophils: regulation by cytokines and correlation with cell survival. Blood, v.92, n. 7, p.2495-2502, 1998.

MURPHY, M.; CHAUBE, S. Preliminary survey of hydroxyurea (nsc-32065) as a teratogen. Cancer Chemother.Rep.,v.40, n.1,p.1-7, 1964.

NADIN, S.; VARGAS-ROIG, L.; CIOCCA, D. A silver staining method for single-cell gel assay. J. Histochem. Cytochem., v.49, n.9, p.1183-1186, 2001.

OHENE-FREMPONG, K.; WEINER, S.J.; SLEEPER, L.A.; MILLER, S.T.; EMBURY, S.; MOOHR, J.W.; WETHERS, D.L.; PEGELOW, C.H.; GILL, F.M. Cerebrovascular accidents in sickle cell disease: rates and risk factors. Blood, v.91, n.1, p.288-294, 1998.

OKAPALA, I. Leukocyte adhesion cell disease. Curr.Opin. Hematol., v.13, n.1, p.40-44, 2006. 
OKPALA, I. The intriguing contribution of white blood cells to sickle cell disease - a red cell disorder. Blood Rev., v.18, n.1,p.65-73, 2004.

OPPENHEIM, J.J.; FISHBEIN, W.N. Induction of chromosome breaks in cultured normal human leukocytes by potassium arsenite, hydroxyurea and related compounds. Cancer Res.,v.25, n.7, p.980-985, 1965.

ORAH, S.; PLATT, M.D. Hydroxyurea for the treatment of sickle cell anemia. N. Engl. J. Med.,v.358, p.1362-1369, 2008.

PLATT, O.S.; BRAMBILLA, D.J.; ROSSE, W.F.; MILNER, P.F.; CASTRO, O.; STEINBERG, M.H.; KLUG, P.P. Mortality in sickle cell disease. Life expectancy and risk factors for early death. N. Engl. J. Med., v.330, n.23, p.16391644, 1994.

PLATT, O.S.; ORKIN, S.H.; DOVER, G.; BEARDSLEY, G.P.; MILLER, B.; NATHAN, D.G. Hydroxyurea enhances fetal hemoglobin production in sickle cell anaemia. J. Clin. Invest., v.74, n.2, p.652-656, 1984.

REES, D.C.; GIBSON, J.S. Biomarkers in sickle cell disease. Br. J. Haematol., v.156, n.4,p.433-445, 2011.

RENZI, D.; VALTOLINA, M.; FORSTER, R. The evaluation of a multi-endpoint cytotoxicity assay system. ATLA Altern. Lab. Anim., v.21, n.1, p.89-96, 1993.

ROCHA, L.B.S.; ELIAS, D.B.D.; BARBOSA, M.C.; BANDEIRA, I.C.J.; GONÇALVES, R.P. DNA damage in leukocytes of sickle cell anemia patients is associated with hydroxyurea therapy and with $\mathrm{HBB}^{*} \mathrm{~S}$ haplotype. Mutat. Res., v.749, n.1-2, p.48-52, 2012.

SAIKI, R.K.; SCHARF, S.; FALOONA, F.; MULLIS, K.B.; HORN, G.; ERLICH, H.A.; ARNHEIM, N. Enzymatic amplification of beta-globin genomic sequences and restriction site analysis for diagnosis of sickle cell anemia. Science, v.230, n.4732, p.1350-1354, 1985.

SANTOS, J.L.; BOSQUESI, P.L.; ALMEIDA, A.E.; CHIN, C.M.; VARANDA, E.A. Mutagenic and genotoxic effect of hydroxyurea. Int. J. Biomed. Sci., v.7, n.4, p.263-267, 2011.

SCHULTZ, W.H.; WARE, R.E. Malignancy in patients withsickle cell disease. Am. J. Hematol., v.74, n.4, p.249253,2003
SEGAL, J.B.; STROUSE, J.J.; BEACH, M.C.; HAYWOOD, C.; WITKOP, C.; PARK, H.S.; WILSON, R.F.; BASS, E.B.; LANZKRON, S. Hydroxyurea for the treatment of sickle cell disease. Evid. Rep. Technol. Assess., n.165, p.195, 2008.

SEGEL, G.B.; HALTERMAN, M.W.; LICHTMAN, M.A. The paradox of the neutrophil's role in tissue injury. J.Leukoc. Biol., v.89, n.3, p.359-372, 2011.

SINGH, N.; MCCOY, M.; TICE, R.; SCHNEIDER, E. A simple technique for quantitation of low levels of DNA damage in individual cells. Exp. Cell Res., v.175, n.1, p.184-191, 1988.

STEINBERG, M.H. Sickle cell anemia, the first molecular disease: overview of molecular etiology, pathophysiology, and therapeutic approaches. Sci. World J., v.8, p.1295-1324, 2008.

STEINBERG, M.H.; MCCARTHY, W.F.; CASTRO, O.; BALLAS, S.K.; ARMSTRONG, F.D.; SMITH, W.; ATAGA, K.; SWERDLOW, P.; KUTLAR, A.; DECASTRO, $\mathrm{L}$. The risks and benefits of long-term use of hydroxyurea in sickle cell anemia: A 17.5 year follow-up. Am. J. Hematol., v.85, n.6, p.403-408, 2010.

STEINBERG, M.H.; VOSKARIDOU, E.; KUTLAR, A.; LOUKOPOULOS, D.; KOSHY, M.; BALLAS, S.K.; CASTRO, O.; BARTON, F. Concordant fetal hemoglobin response to hydroxyurea in siblings with sickle cell disease. Am. J. Hematol., v.72, n.2, p.121-126, 2003.

STRICKER, R.B.; LINKER, C.A.; CROWLEY, T.J.; EMBURY, S.H. Hematologic malignancy in sickle cell disease: report of four cases and review of the literature. Am. J. Hematol., v.21, n.2, p.223-230, 1986.

TICE, R.R.; AGURELL, E.; ANDERSON, D.; BURLINSON, B.; HARTMANN, A.; KOBAYASHI, H.; MIYAMAE, Y.; ROJAS, E.; RYU, J.C.; SASAKI, Y.F. Single cell gel/comet assay: guidelines for in vitro and in vivo genetic toxicology testing. Environ. Mol. Mutagen., v.35, n.3, p.206-221, 2000.

WARE, R.E.; AYGUN, B. Advances in the use of hydroxyurea. ASH Educ. Program Book, v.2009, n.1, p.62-69, 2009.

WARE, R.E. How I use hydroxyurea to treat young patients with sickle cell anemia. Blood, v.115, n.26, p.5300-5311, 2010. 
ZAGO, M.A.; PINTO, A.C.S. Fisiopatologia das doenças falciformes: da mutação genética à insuficiência de múltiplos órgãos. Rev. Bras. Hematol. Hemoter., v.29, n.3, p.207-214, 2007.

Received for publication on $06^{\text {th }}$ October 2013 Accepted for publication on $14^{\text {th }}$ January 2014 